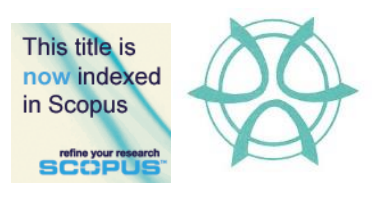

PLANNING MALAYSIA:

Journal of the Malaysian Institute of Planners

VOLUME 16 ISSUE 2 (2018), Page 89 - 98

\title{
DETERMINING HOUSING AFFORDABILITY FOR YOUNG PROFESSIONALS IN KLANG VALLEY, MALAYSIA: RESIDUAL INCOME APPROACH
}

\author{
Nor Suzylah Sohaimi ${ }^{1}$, Alias Abdullah ${ }^{2}$ \& Syafiee Shuid ${ }^{3}$ \\ ${ }^{1}$ College of Law, Government and International Studies \\ UNIVERSITI UTARA MALAYSIA \\ ${ }^{2,3}$ Kulliyyah of Architecture and Environmental Design \\ INTERNATIONAL ISLAMIC UNIVERSITY MALAYSIA
}

\begin{abstract}
Underprivileged young professionals in housing affordability are prone to an adverse effect on their well-being. This article empirically examines housing affordability among young professionals aged between 25 and 35 years old who work or live in Klang Valley. Young professionals in this paper refer to young graduates with at least a Bachelor's degree and are registered to professional institutions such as the Institution of Engineers Malaysia (IEM), Malaysian Institute of Architects (MIA), Malaysian Institute of Planners (MIP), and Royal Institution of Surveyor Malaysia (RISM). The aim of this study is to measure housing affordability based on residual income approach and to identify the attribute that affects young professionals' housing affordability. Adequacy of household income for monthly mortgage or rent as well as other non-housing goods is reflecting for housing affordability. Attributes namely occupation, the presence of children, household expenditure, transportation cost, vehicle instalment, education loan, and household income are analysed by using binary logistic regression. 264 respondents who are either a homeowner, tenant, or parental home resident were selected by using simple random sampling. The survey data were collected through the professional institutions respectively. The study found that only presence of children, occupation of urban planner and education loan III (not taking a loan) were insignificant to the model.
\end{abstract}

Keywords: young professionals, housing affordability, residual income approach, binary logistic regression 
Nor Suzylah Sohaimi, Alias Abdullah \& Syafiee Shuid

Determining Housing Affordability for Young Professionals in Klang Valley, Malaysia: Residual Income Approach

\section{INTRODUCTION}

Housing affordability issues are ubiquitous in the housing market. Previous academicians emphasised on the affordability for the middle-income group (Bujang, Anthony Jiram, Abu Zarin, \& Md. Anuar, 2015) and only beginning from year the 2013, housing affordability among Gen Y is discussed at the local level. Undoubtedly, Gen Y is receiving a devastating effect as their income is not parallel to the current housing price. Recent evidence reveals that new residence priced lower than MYR 250,000 in the Klang Valley is considered non-existent since 2014 (Khazanah Research Institute, 2015). The young professionals (YPs) are required to repay their education loan after six months of graduation and failure to do so will cause them to be listed to the Central Credit Reference Information System (CCRIS). Education loan is the criterion that distinguishes YPs from other young cohort who are not burdened with this debt. Simultaneously, other non-housing goods are required for sustaining the generation's well-being. Besides food and beverage, transportation possession, for instance, is seen as a necessity to meet the mobile nature of their career. Consequently, education loan and transportation cost are ineluctable features in determining YPs' housing affordability. Other factors are also discussed in this study.

\section{LITERATURE REVIEW}

\section{Housing Affordability Approaches}

A plethora of methodologies have been used to study housing affordability and they have been documented in voluminous working papers. The price to income ratio (PIR) approach is accepted by practitioners worldwide (Jewkes \& Delgadillo, 2010) and considered as a prominent approach as it is easily computed and apprehended (Belsky, Goodman, \& Drew, 2005). Accordingly, this approach computes that the standard for housing affordability is assumed to be met when $30 \%$ or less of gross household income is spent for housing cost. Another almost identical approach to PIR is housing expenditure to income ratio (HEIR), in which $25-30 \%$ benchmark is used. Precisely, the concept assumed one week's pay for one month's rent (Hulchanski, 1995). Initially, the market basket approach (MBA) was revealed in 1975, which is different from others as it is based on adequacy of remaining income for household expenditure after paying housing cost. The household is seen to meet housing affordability if they have adequate money left for household expenditure.

Similarly, the residual approach employs almost duplicate standpoint with the MBA, in which sufficiency for household expenditure cost are signified for affordability (Henman \& Jones, 2012). However, the residual approach emphasises more on household sustainability. From this perspective, a household is seen to have housing affordability if they meet the expense of housing cost and 
other necessities and this definition also cogitates housing quality (Henman \& Jones, 2012).

Overall, one criticism of the PIR approach is that it excludes the nonhousing cost and disregards the diversity of the household. In fact, the $30 \%$ of affordability benchmark is different from the diversity of the housing market (O'Dell, Smith, \& White, 2004). Hence, using the percentage as a rule of thumb in determining housing affordability is debatable. In this respect, the household might have the capability for mortgage or rental payment if 25 to $30 \%$ of income is used to determine affordability, but undeniably the household is inclined to drop below the poverty line if their other necessities at the minimum level cannot be met. Tconfusion.hen, with regard to household size, for instance, couples without children are more likely to be able to afford a mortgage and meet other necessities easily as they have a small household size compared to couples who have children. Another drawback of PIR, HEIR, and MBA is that they do not take into account the housing quality.

Consequently, the residual is seen an appropriate approach as it not merely considers the housing affordability, but also the household capacity to meet the standard of living. In the similar vein, the residual is also associated with 'shelter poverty' benchmark (Stone, Burke, \& Ralston, 2011), in which the household with irrelevant living standard is considered as unaffordable for housing and observed as being in shelter poverty. Another equally important point is that the residual is also sensitive to the household structure and diverse income level.

Despite that, one great puzzling question is that what is a budget indicator for the household expenditure, as the household diversity might be different from one another. This issue also receives attention among international scholars specifically in Australia and as a result, they summarised nine budget indicators, namely housing cost, energy, food, clothing, household goods and services, health, transportation, leisure, and personal care (Henman \& Jones, 2012). In local context, a study on housing affordability with the residual approach had been carried out, but the study neglected the budget indicator and instead asked respondents for the total household expenditure (Sani, 2015). Accordingly, this study has been improved, in which the budget indicator from the Department of Statistics, Malaysia and Bank Negara Malaysia was employed for this study. With regard to this matter, twelve indicators were studied, namely food and nonalcoholic beverage, alcoholic beverage and tobacco, clothing and footwear, utilities, household maintenance, health, transport, communication, recreation services and culture, education, restaurants and hotels, and miscellaneous goods and services.

The residual approach is computed by deducting the housing cost and household expenditure from household income. In this case, mortgage instalment and rental are used to measure affordability for homeowners and tenants. 
Nor Suzylah Sohaimi, Alias Abdullah \& Syafiee Shuid

Determining Housing Affordability for Young Professionals in Klang Valley, Malaysia: Residual Income Approach

Meanwhile, those who live in parental homes were asked about their intention of buying a home in the near future, house price target, and location. A simulation is made by supported the mortgage loan calculator to identify the prospective home buyers' affordability to pay mortgage instalment. Based on this, the prospect's mortgage instalment is used to compute their affordability.

\section{Predictors Descriptions}

With regard to determining housing affordability, household income is a ubiquitous predictor that cannot be deserted (Osman, Khalid, \& Yusop, 2017). Household income in the study is defined as a single income for a single person and dual income if the husband and spouse are working while other breadwinners in the household such as relative members were disregarded. Only permanent income was counted in the study and the household income questions in the survey were presented as open-ended questions.

Another compelling point in this paper was gathering the information on household expenditure adequacy. Therefore, the respondents were required to declare their household expenses based on the indicator given. Similarly, the respondents were required to provide transportation cost based on features such as petrol, toll, car park, train ticket, service charge, vehicle's monthly instalment, insurance, and other expenses that are linked to their transportation. Yet again, an open-ended question was used for this section.

This study aims to determine YPs' housing affordability; hence, education loan is appropriate to be investigated because the target respondents obtained their tertiary education by applying education loans, while some others received scholarships. In this respect, how the education loan possession affect housing affordability was studied extensively. In the survey, education loan was decoded by a nominal scale; YES for those taking education loans and NO for those being under scholarship or supported by parents and not taking loans. An equally important aspect of this study is that it also examines how an individual with different professions differ in their housing affordability. As mentioned before, four professions were involved in the study. Another demographic question of the study was about the status of the presence of children in the household and how it affects YPs' housing affordability. 
PLANNING MALAYSIA

Journal of the Malaysia Institute of Planners (2018)

\section{RESPONDENTS' BACKGROUND}

YPs are respondents in the study and referred as those with at least a Bachelor's degree which aligns with Malaysia Standard Classification of Occupations benchmark (Ministry of Human Resources Malaysia, 2010). The benchmarking of YPs' age is adopted from the late youth cohort definition which ranges between 25 to 35 years old (Hamzah et. al., 2007). In contrast, age between 15 and 40 has been accepted broadly in Malaysian perspective, but this range is open to dispute. In this respect, they are considered to have one or two years of working experience cumulatively when the range 25 to 35 is referred as YPs. Another essential point is that YPs are narrowed from the built environment area to four professions namely engineer, architect, urban planner, and quantity surveyor. Prominently, these professions have been accredited by professional institutions and set out in profession act respectively. Additionally, YPs were restricted to those working or living in Klang Valley. Then, this cohort is considered as falling within the M40 group, with household income approximately MYR 3860 to MYR 8320. However, in the factual data, it was found that there were also YPs who received a salary under MYR 3860.

\section{METHODOLOGY}

A probability sampling method was used to collect data of four professions from professional institutions such as the IEM, MIA, and MIP, and RISM. A sample of 264 respondents was random selected using self-administered and researcheradministered methods. The sample size has been determined as shown in Table 1.

Table 1: Population and sample size of young professionals

\begin{tabular}{cccccc}
\hline Profession & Engineer & Architect & $\begin{array}{c}\text { Urban } \\
\text { Planner }\end{array}$ & QS & Total \\
\hline Population & 110 & 75 & 60 & 80 & 325 \\
Sample Size & 86 & 60 & 51 & 67 & 264 \\
\hline Source: This study & & & &
\end{tabular}

Data were collected between January 2017 and April 2017 in the Klang Valley. The data involved a mix of categorical and continuous variables. Consequently, the questionnaire was designed with open ended and nominal question form. The binary logistic regression, therefore, was used to analyse the data. The housing affordability levels were measured at two levels, where Level 1 means that the housing is affordable while Level 0 is not affordable. Then, the relationship between the independent and dependent variables is not a linear function in logistic regression, but the logistic regression function is applied by the logit transformation of $\Theta$ : 
Nor Suzylah Sohaimi, Alias Abdullah \& Syafiee Shuid

Determining Housing Affordability for Young Professionals in Klang Valley, Malaysia: Residual Income Approach

$$
\Theta=\frac{e\left(\alpha+\beta 1^{\chi} 1+\beta 2^{\chi} \chi_{2}+\ldots .+\beta i \chi_{i}\right)}{1+e\left(\alpha+\beta 1^{\chi} 1+\beta 2^{\chi} \chi_{2}+\ldots+\beta i \chi_{i}\right)}
$$

Where:

$\Theta=$ the probability that a case is in a particular category $\boldsymbol{e}=$ the base of natural logarithms (approx. 2.72)

$\boldsymbol{\alpha}=$ the constant of the equation

$\boldsymbol{\beta}=$ the coefficient of the independent variables

\section{RESULTS AND ANALYSIS}

The ownership type for the study is divided into three categories which comprises homeownership, rent, and parental home. However, the respondents who are renting and living with family were asked about affordability for buying a house with the reasonable and affordable price at the location of their choice. Housing affordability with residual approach is defined by employing the following rule:

$$
\begin{aligned}
& \text { Housing Monthly - Housing - Monthly } \\
& \text { Affordability = Household Cost Household } \\
& \text { Income Expenditure }
\end{aligned}
$$

Referring to the equation above, the household is considered as having housing affordability if they have remaining income (positive amount) after deduction for housing cost and household expenditure and vice versa.

The outcomes in Table 2 were computed by employing this equation. The value of $1 *$ in Table 2 is referred as having housing affordability while $0 * *$ as not having housing affordability. Table 2 compares the housing affordability among four professions and is divided into three types of ownership. At first glance, it is evident that most of YPs (109 respondents) are renting, followed by homeownership (84), and living at parental home (72). With regard to housing affordability of homeownership and renting, all four professions (about 70 and 95 respondents) had affordability respectively and only 14 respondents for each home ownership and renting were seen as having difficulty. Interestingly, when the respondents from renting market and parental home were asked about buying a home in the near future, it was evident from about 99 respondents that they cannot afford to buy a home and only 79 respondents were shown as having affordability. 
PLANNING MALAYSIA

Journal of the Malaysia Institute of Planners (2018)

Table 2: Housing affordability among young professionals

\begin{tabular}{|c|c|c|c|c|c|c|c|c|c|c|}
\hline \multirow{3}{*}{ Professions } & \multicolumn{10}{|c|}{ Ownership Type } \\
\hline & \multicolumn{2}{|c|}{$\begin{array}{c}\text { Home } \\
\text { ownership }\end{array}$} & & & \multicolumn{2}{|c|}{ Rent } & \multicolumn{2}{|c|}{$\begin{array}{c}\text { Family } \\
\text { Residence }\end{array}$} & \multicolumn{2}{|c|}{$\begin{array}{c}\text { Prospect } \\
\text { Buying }\end{array}$} \\
\hline & $1 *$ & $0 * *$ & Total & $1 *$ & $0 * *$ & Total & $\begin{array}{c}1 * 0 * * \\
\text { Total }\end{array}$ & $1 *$ & $0 * *$ & Total \\
\hline Engineer & 23 & 4 & 27 & 37 & 4 & 41 & 18 & 36 & 22 & 58 \\
\hline Architect & 25 & 6 & 31 & 15 & 2 & 17 & 13 & 12 & 17 & 29 \\
\hline $\begin{array}{c}\text { Urban } \\
\text { Planner }\end{array}$ & 10 & 1 & 11 & 24 & 4 & 28 & 13 & 14 & 26 & 40 \\
\hline $\begin{array}{l}\text { Quantity } \\
\text { Surveyor }\end{array}$ & 12 & 3 & 15 & 19 & 4 & 23 & 28 & 17 & 34 & 51 \\
\hline Total & 70 & 14 & 84 & 95 & 14 & 109 & 72 & 79 & 99 & 178 \\
\hline
\end{tabular}

A logistic regression analysis was conducted to predict housing affordability among 264 young professionals. The result of the logistic regression analysis in Table 3 indicates that the nine independent variables model provided a statistically significant improvement over the constant model, model $\chi^{2}(9, N=$ 264 chi square $=120.327, p<0.05$ with $d f=10$. The Nagelkerke pseudo $\mathrm{R}^{2}$ indicated that the model accounted for $52.2 \%$ of variance. The prediction success was relatively high; for those who could not afford for housing affordability was $64.9 \%$, for those who could afford for housing affordability was $89.3 \%$, and the overall accuracy was $82.2 \%$. Table 3 presents the full results. From the Wald test report, nine predictors which consisted of Engineer, Architect, Quantity Surveyor, Total Household Expenditure, Total Transportation Cost, Vehicle Instalment, Total Household Income, Education Loan I (taking loan), and Education Loan III (full settlement) were significant contributors to housing affordability while Urban Planner, Education Loan II (not taking education loan), and Presence of Children were not significant contributors to the model.

Referring to Table 3 , it is noticeable that the significant value for predictors of Urban Planner, Education Loan II, and Presence of Children were more than 0.05 ( $p>0.05)$. The influence of Education Loan III (full settlement) was very strong. $\operatorname{Exp}(B)$ value indicated that when Education Loan III is raised by one unit, the odds ratio is 25 times as large. Then, to make certain whether the predicted probabilities match the observed probabilities or not, the Hosmer and Lemeshow test was conducted. With regard to this matter, a significance value of more than 0.05 indicates that the model is fit. This study also indicated that the Hosmer and Lemeshow test is fit when the significance value was 0.460 . 
Nor Suzylah Sohaimi, Alias Abdullah \& Syafiee Shuid

Determining Housing Affordability for Young Professionals in Klang Valley, Malaysia: Residual Income Approach

Table 3: Determinants of young professionals' housing affordability: Binary logistic

\begin{tabular}{|c|c|c|c|c|c|c|c|c|}
\hline \multirow[t]{2}{*}{ Variable } & \multirow[b]{2}{*}{ B } & \multirow[t]{2}{*}{ S.E } & \multirow[t]{2}{*}{ Wald } & \multirow[t]{2}{*}{ df } & \multirow[t]{2}{*}{ Sig. } & \multirow[t]{2}{*}{$\begin{array}{l}\text { Exp } \\
\text { (B) }\end{array}$} & \multicolumn{2}{|c|}{$\begin{array}{ll}95 \% & \text { C.I for } \\
\operatorname{EXP}(B) & \end{array}$} \\
\hline & & & & & & & Lower & Upper \\
\hline Engineer & & & 15.818 & 3 & .001 & & & \\
\hline Architect & -1.057 & .530 & 3.978 & 1 & .046 & .348 & .123 & .982 \\
\hline Urban Planner & .186 & .538 & .120 & 1 & .729 & 1.205 & .420 & 3.458 \\
\hline Quantity Surveyor & -1.684 & .506 & 11.068 & 1 & .001 & .186 & .069 & .501 \\
\hline $\begin{array}{l}\text { Total Household } \\
\text { Expenditure }\end{array}$ & -.002 & .001 & 9.628 & 1 & .002 & .998 & .997 & .999 \\
\hline Total transportation cost & -.003 & .001 & 18.905 & 1 & .000 & .997 & .996 & .998 \\
\hline Vehicle Instalment & .003 & .001 & 7.378 & 1 & .007 & 1.003 & 1.001 & 1.005 \\
\hline $\begin{array}{l}\text { Total household income } \\
\text { Education Loan I (Taking } \\
\text { loan) }\end{array}$ & .001 & .000 & $\begin{array}{l}29.056 \\
6.629\end{array}$ & $\begin{array}{l}1 \\
2\end{array}$ & $\begin{array}{l}.000 \\
.036\end{array}$ & 1.001 & 1.001 & 1.002 \\
\hline $\begin{array}{l}\text { Education Loan II (Not } \\
\text { Taking loan) }\end{array}$ & 2.409 & 1.570 & 2.353 & 1 & .125 & 11.123 & .512 & 241.532 \\
\hline $\begin{array}{l}\text { Education Loan III (Full } \\
\text { Settlement) }\end{array}$ & 3.219 & 1.610 & 3.996 & 1 & .046 & 25.005 & 1.065 & 587.132 \\
\hline Presence of Children & -.642 & .637 & 1.016 & 1 & .313 & .526 & .151 & 1.834 \\
\hline Constant & -1.521 & 1.834 & .688 & 1 & .407 & .219 & & \\
\hline
\end{tabular}

a. Variable(s) entered on step 1: Occupation, Total Household Expenditure, Total Transportation

Cost, Vehicle Instalment, Total Household Income, Education Loan, Presence of Children.

b. Pseudo $\mathrm{R}^{2} 0.522$

Source: This study

\section{DISCUSSION AND CONCLUSION}

The most obvious finding from this study is that most YPs able to afford houses whether as homeowners, renting, or prospect homeowners, and are concurrently preserving their living standard without dropping below the poverty line. Nevertheless, the fact of the matter is that the number of respondents in the renting market was outnumbered by homeownership (109 to 84 YPs). The decision to rent was due to work as some YPs, especially civil engineers and architects, were required to be mobile as their jobs were on a contract basis. However, there were also respondents who could not afford to buy houses in the current market; therefore they remained in the renting market. Meanwhile, YPs who had families in Klang Valley were seen as more fortunate as they could live at their families' residence. Another key empirical outcome was that the number of YPs who could not afford to buy a house in the near future was outstripped to those who could afford by 20 respondents ( 99 to 79). This result indicated that 99 YPs needed to be addressed as they were considered to be adversely impacted on the housing affordability issue.

Investigation of factors that influence housing affordability found that total household expenditure, total transportation cost, vehicle instalment, total household income, taking education loan, taking education loan with full 
settlement, professions such as engineer, architect, and quantity surveyor had significant contributions to the model. As anticipated, total household income, household expenditure, transportation cost, and education loan were influential to housing affordability.

In fact, household income was a ubiquitous predictor in many previous researches. In a different research, difficulty in providing a deposit, insufficient affordable house supply, house size preferences and struggle to secure the loan contributed to the housing affordability issue (Bujang et al., 2015). However, this particular study is emphasising merely on assessment of household expenses toward housing affordability.

In this study, vehicle instalment has a substantial effect to housing affordability. Prior to the study, an investigation concerning Malaysian millennials' debt was conducted and it was discovered that hire purchase loan was the most common cause for debt, approximately $56 \%$ of young people were burdened by it. It is irrefutable that YPs require transportation for work. For instance, an engineer requires a vehicle to facilitate movement between office and project sites; this circumstance is equivalent to other professions. From this perspective, YPs who just started to join the job market have propensities to establish themselves by applying hire purchase loans. The circumstance is exacerbated if they are more attracted to pursue the high segment cars which are associated with high costs for car instalments and eventually having the potential to eliminate housing affordability. The existence of the graduate car scheme for instance, encourage YPs to buy a car without a down payment and the leniency of the scheme is an ensnarement to the issue. Furthermore, one must bear in mind that they are not merely responsible for the car instalment but simultaneously other costs related to their vehicle such as insurance, tax, service, and maintenance.

Contrary to expectations, this study did not find a significant contribution of the predictor of presence of children to the housing affordability. Initially, the presence of children has been hypothesised to affect housing affordability because household expenditure is sensitive to an increase in the household size, which influences affordability. In spite of that fact, the result indicated that YPs' housing affordability was not improved regardless of the household having children or not. Another two predictors, Urban Planner and Education Loan III (not taking loan), also did not affect affordability. In this respect, YPs who do not take education loan understandably have a more privileged financial condition after graduation; therefore, they are less burden for paying education loan and have less risk to be listed in CCRIS that eliminates their probability for buying a house. Meanwhile, the profession as an urban planner has less effect to affordability issue. The reason behind this case is because more urban planners are renting instead of owning a home, as sharing a rental house with friends is most affordable. 
Nor Suzylah Sohaimi, Alias Abdullah \& Syafiee Shuid

Determining Housing Affordability for Young Professionals in Klang Valley, Malaysia: Residual Income Approach

\section{REFERENCES}

Belsky, E. S., Goodman, J., \& Drew, R. (2005). Measuring the nation's rental housing affordability problems. Cambridge, MA: Joint Center for Housing Studies, Graduate School of Design John F. Kennedy School of Government, Harvard University.

Bujang, A. A., Anthony Jiram, W. R., Abu Zarin, H., \& Md. Anuar, F. H. (2015). Measuring the gen $\mathrm{Y}$ housing affordability problem. International Journal of Trade, Economics and Finance, 6(1), 22-26.

Hamzah, A., Krauss, S. E., Noah, S. M., Suandi, T., Juhari, R., Manap, J.,..\& Kassan, H. (2007). Muslim religiosity and personality assessment: Prototype for nation building. Serdang, Selangor: Institute for Social Sciences Studies (IPSAS)University Putra Malaysia.

Henman, P., \& Jones, A. (2012). Exploring the use of residual measures of housing affordability in Australia: Methodologies and concepts. AHURI Final Report No. 180, Australian Housing and Urban Research Institute Limited, Melbourne, https://www.ahuri.edu.au/research/final-reports/180.

Hulchanski, J. D. (1995). The concept of housing affordability: Six contemporary uses of the housing expenditure-to-income ratio. Housing Studies, 10(4), 471-491.

Jewkes, M. D., \& Delgadillo, L. M. (2010). Weaknesses of housing affordability indices used by practitioners. Journal of Financial Counseling and Planning, 21(1). Retrieved from https://papers.ssrn.com/sol3/papers.cfm?abstract_id=2222052

Khazanah Research Institute (2015). Making housing affordable. Kuala Lumpur: Author.

Ministry of Human Resources Malaysia (2010). Malaysia standard classification of occupations.

O’Dell, W., Smith, M. T., \& White, D. (2004). Weaknesses in current measures of housing needs. Housing and Society, 31(1), 29-40.

Osman, M. M., Khalid, N., \& Yusof, S. W. M. (2017). Housing affordability in the state of Selangor, Malaysia. Advanced Science Letters, 23(7), 6118-6122.

Sani, N. M. (2015). Relationship between housing affordability and house ownership in Penang. Jurnal Teknologi, 75(9), 65-70.

Stone, M. E., Burke, T., \& Ralston, L. (2011). The residual income approach to housing affordability: The theory and practice. AHURI Positioning Paper No. 139, Australian Housing and Urban Research Institute Limited, Melbourne, https://www.ahuri.edu.au/research/position-papers/139. 